\title{
Tolerance of 'Camarosa' Strawberry (Fragaria $\times$ ananassa Duch.) to Extra-label Use of Single and Tank Mix Preemergence Herbicides in Annual Hill Plasticulture
}

\author{
Edgar L. Vinson III \\ Department of Horticulture, Auburn University, Auburn, AL 36849
}

Kaitlyn J. Price

Department of Crop, Soil, and Environmental Science, Auburn University, Auburn, AL 36849

J. Raymond Kessler and Elina D. Coneva

Department of Horticulture, Auburn University, Auburn, AL 36849

\begin{abstract}
Masuzyo Mwanza
Department of Mathematics and Statistics, Auburn University, Auburn, AL 36849
\end{abstract}

\section{Matthew D. Price \\ Alabama Agricultural Experiment Station, Auburn University, Auburn, AL 36849}

Additional index words. herbicide tolerance, Southeast, tank mix application, weed management

\begin{abstract}
Relatively few herbicides are registered in Alabama or in the southeastern United States for use in annual hill plasticulture production of strawberries. Acquisition of 24(c) special local needs status for certain herbicides could make more of these chemistries available to the strawberry industry. These herbicides, especially when applied as tank mixes pose potential risks to strawberry plant growth and fruit yield. Special local needs status for these herbicides has been granted for other states, but more evaluation of these products in Alabama soils under plastic mulch is needed. The objective of this study was to assess tank mix applications of preemergence herbicides with different modes of action on plant growth, crop yield, and fruit size of 'Camarosa' strawberry. A study was conducted at the Chilton Research and Extension Center in Clanton, AL, in 2018 and 2019. Pendimethalin $\left(3.5 \mathrm{~L}^{\cdot h^{-1}}{ }^{-1}\right)$ and $S$-metolachlor $\left(1.6 \mathrm{~L} \cdot \mathrm{ha}^{-1}\right)$ were evaluated for potential phytotoxicity in 'Camarosa' strawberry when applied alone or in tank mixes with napropamide $\left(8.6 \mathrm{~kg} \cdot \mathrm{ha}^{-1}\right)$, sulfentrazone $\left(0.3 \mathrm{~L} \cdot \mathrm{ha}^{-1}\right)$, or terbacil $\left(0.42 \mathrm{~L} \cdot \mathrm{ha}^{-1}\right)$ by comparing them to a nontreated control. At 18 weeks after planting, pendimethalin tank mixed with napropamide reduced plant dry weight by $33 \%$ compared with the control, but this reduction was not significant. Additionally, tank mixes of pendimethalin with sulfentrazone, napropamide, and terbacil reduced shoot dry weight by $43 \%, 52 \%$, and $43 \%$, respectively, compared with pendimethalin alone. Pendimethalin + napropamide tank mix reduced relative growth rate by $95 \%$ compared with the control between 6 and 18 weeks after planting. All treatments were similar to the control in marketable yield. Differences in plant growth parameters did not appear to affect yield by the end of the experiment. All single applied treatments along with $S$-metolachlor tank mixed with napropamide and sulfentrazone; pendimethalin tank mixed with sulfentrazone and terbacil appeared to be safe for direct application to strawberry planting beds covered in polyethylene mulch.
\end{abstract}

Strawberry production in the United States has increased annually since 1994, but high national strawberry demand has not translated into large tracts of land being planted to strawberries proportionately throughout the Southeast. In 2012, there were 74 farm operations in Alabama engaged in strawberry production on a combined 158 acres. By 2017, the number of farm operations increased to 123 , but combined acreage was reduced to 111 (U.S. Department of Agriculture, National Agricultural Statistics Service, 2012). Growers cite difficulties in making profits due in part to a relatively small arsenal of available weed control options (Boyd and Reed, 2016).

Few physical or chemical options have the capacity to sufficiently control economically important weed species in Alabama
(Alabama Cooperative Extension, 2013), such as broadleaves like morning glory (Ipomoea sp.) or yellow or purple nutsedge ( $C y$ perus esculentus and Cyperus rotundus L.). Polyethylene mulches reduce light transmittance and create a physical barrier to weed development (Ngouajio and Ernest, 2004; Yu and Boyd, 2017). Black is often the color of choice because of its opacity and low light transmission $(\approx 1 \%)$ reducing the chances of weed seed germination and weed growth (Brault et al., 2002; Ngouajio and Ernest, 2004). Despite this, weeds may grow in spaces left uncovered by mulch, such as in planting holes (Adcock et al., 2008). Moreover, yellow or purple nutsedge is capable of puncturing and growing through plastic mulch. Hand weeding is laborious, expensive, time-consuming, and impractical because of irregularities in availability of migrant labor ( $\mathrm{Hu}$ et al., 2017; Taylor et al., 2012). Methyl bromide is no longer available for the majority of agricultural enterprises, compounding the weed control issue and further necessitating the need for effective weed control solutions.

Expansion in the number of chemical weed control options would provide considerable assistance to strawberry growers. Figueroa et al. (2005) stated that only $39 \%$ of the strawberry acreage in the United States received herbicides, which was primarily accommodated through the applications of only two chemistries with different modes of action, napropamide and terbacil. Postemergent (POST) herbicides are a mainstay in chemical weed control in most systems, but few are registered in strawberry, and only one, clopyralid, controls broadleaf weeds (Sharpe et al., 2018). Further, POST herbicides applied in excess of 1 or 2 months after planting will have diminished effectiveness in controlling weeds, resulting in increased competition with weeds and reduction of crop yield by $20 \%$ to $60 \%$ (Figueroa et al., 2005; Pritts and Kelly, 2001). Timely application of POST herbicides will depend on favorable climatic conditions or absence of other environmental factors. Including preemergent (PRE) herbicides would be helpful in countering some of these constraints.

Similar to POST herbicides, the list of available PRE herbicides is brief, but there is potential for expansion through 24(c) special local needs registration. The Environmental Protection Agency defines special local needs as approval of states to register a product for use on an existing or imminent pest problem for which there is not a product sufficiently available (epa.gov/ pesticide-registration/guidance-fifra-24c-registrations\#). This classification was sought by and awarded to some states for permission to use clopyralid, but to date, this chemical is not registered for use in strawberries in many states (S. $\mathrm{Li}$, personal communication).

Currently, in the southeastern United States, napropamide and, in some states, sulfentrazone are two PRE herbicides registered as 24(c) for use in strawberries. Granting of 24(c) status to PRE herbicides for extra-label usage in strawberry would make several more chemistries available to growers. Terbacil and pendimethalin are labeled for use in matted-row strawberries and 
in row middles, but the matted row system has been replaced by the more productive annual hill plasticulture system for the commercial production of strawberries in most regions (Butler et al., 2002; Samtani et al., 2019). Currently, sulfentrazone has a special local needs label for Ohio, Tennessee, Michigan, Washington, and Oregon (Spartan 4F, FMC, 2011), whereas $S$ metolachlor (Dual Magnum, Syngenta, 2018) has a special local needs label for Michigan and Oregon. $S$-metolachlor is desirable because of its relatively low price and ability to control yellow nutsedge (Daugovish et al., 2007). It will be useful to determine the effects of these herbicides on growth and yield parameters of strawberries in the hill plasticulture system in Alabama.

Enhancement of PRE herbicides through tank mixes. PRE herbicides can be used alone or in tank mixes with other PRE herbicides, especially those with different modes of action, to increase the efficacy of herbicides or increase the number of weed species controlled (Kaushik et al., 2006; Recker et al., 2015). In a potato study, tank mixes of metribuzin + pendimethalin and linuron + fluazifop-P-butyl were the most effective treatments for weed control and provided the highest yields (Mišović et al., 1997). In addition, Awan et al. (2015) determined that application of herbicides with different modes of action in dryseeded rice production was necessary due to high weed pressure and the inability of a single mode of action to control multiple weed types. Tank mixes of PRE herbicides increased yields without causing crop injury in other cropping systems providing opportunity and support for their use in strawberry production. Boyd and Reed (2016) found that $S$-metolachlor in a tank mix with oxyfluorfen could be applied through the drip tape in as few as $24 \mathrm{~h}$ before planting without causing injury to strawberries.

Tank mixes can provide a larger measure of weed protection, but application may increase the risk of phytotoxicity (Singh et al., 2011). Selective herbicides have reduced photosynthesis and induced stress responses in rice (Oryza sati$v a$ ). Furthermore, $S$-metolachlor, sulfentrazone, or pendimethalin have been shown to reduce yield in strawberry (Boyd and Reed, 2016).

The objective of this study was to determine effects of nonregistered or extra-label usage of PRE herbicides applied alone or in tank mixes on growth and yield parameters in strawberry grown in an annual hill plasticulture system. Findings obtained from this study may serve as a foundation for the acquisition of 24 (c) special local needs re labeling leading to immediate availability of previously nonregistered materials creating a broader spectrum of available herbicide chemistries.

Received for publication 7 Dec. 2020. Accepted for publication 2 Mar. 2021.

Published online 30 April 2021.

E.L.V. is the corresponding author. E-mail: vinsoed@auburn.edu.

This is an open access article distributed under the CC BY-NC-ND license (https://creativecommons.org/licenses/by-nc-nd/4.0/).

\section{Materials and Methods}

A study was established at the Chilton Research and Extension Center (CREC) in Clanton, $\mathrm{AL}$, on a Luverne fine sandy loam soil (lat. $32^{\circ} 55^{\prime} 08^{\prime \prime} \mathrm{N}$, long. $86^{\circ} 40^{\prime} 23^{\prime \prime} \mathrm{W}$ ). In 2018, strawberries were planted into soil following successive years of wheat (Triticum aestivum), whereas in 2019, the trial followed a wheat-watermelon (Citrullus linatus) rotation. To make the soil more pliable for enhanced bed formation, water was supplied to the soil after tillage using a $25 \mathrm{~A}$ portable irrigation reel with retractable hose and a 22-mm nozzle impact sprinkler (KIFCO, Havana, IL). Water pressure was $60 \mathrm{PSI}$, and the reel traveled at a rate of $30.5 \mathrm{~m} \cdot \mathrm{h}^{-1}$ and delivered 2.5 $\mathrm{mm}$ of water per hour. Planting beds were formed using a Kennco bedder and plastic mulch layer (Kennco Mfg. Inc., Ruskin, FL). Rows (beds) were spaced $1.8 \mathrm{~m}$ apart. Experimental plots were $9 \mathrm{~m}$ long. Alleys $1.5 \mathrm{~m}$ in length separated experimental plots within the same row. Fertilizer recommendation according to the Alabama Cooperative Extension Service were followed (Himelrick et al., 2002). Fertilizer in the form of $13 \mathrm{~N}-$ 5.7P-10.8K was broadcast applied using a Gandy 10T fertilizer spreader (Owatonna, $\mathrm{MN})$ at a rate of $116 \mathrm{~kg} \cdot \mathrm{ha}^{-1} \mathrm{~N}, 56 \mathrm{~kg} \cdot \mathrm{ha}^{-1} \mathrm{P}$, and $97 \mathrm{~kg} \cdot \mathrm{ha}^{-1} \mathrm{~K}$ and a rate of $146 \mathrm{~kg} \cdot \mathrm{ha}^{-1} \mathrm{~N}$, $64 \mathrm{~kg} \cdot \mathrm{ha}^{-1} \mathrm{P}$, and $121 \mathrm{~kg} \cdot \mathrm{ha}^{-1} \mathrm{~K}$ before bed formation in 2018 and 2019 seasons, respectively. Using a Hozon siphon fertilizer injector (Phytotronics Inc., Earth City MO), 10N$4.4 \mathrm{P}-8.3 \mathrm{~K}$ was injected through the irrigation system with at a rate of $0.11 \mathrm{~kg} \cdot \mathrm{ha}^{-1} \mathrm{~N}, 0.50$ $\mathrm{kg} \cdot \mathrm{ha}^{-1} \mathrm{P}$, and $0.90 \mathrm{~kg} \cdot \mathrm{ha}^{-1} \mathrm{~K}$ on $28 \mathrm{Feb} .2018$ and on 15 Mar. 2018. On 13 Apr. 2018, $10 \mathrm{~N}-4.4 \mathrm{P}-8.3 \mathrm{~K}$ was injected at a rate that supplied $0.22 \mathrm{~kg} \cdot \mathrm{ha}^{-1} \mathrm{~N}, 1 \mathrm{~kg} \cdot \mathrm{ha}^{-1} \mathrm{P}$, and 18.6 $\mathrm{kg} \cdot \mathrm{ha}^{-1} \mathrm{~K}$. On $27 \mathrm{Mar}$. 2018, $0.22 \mathrm{~kg}$ of $10 \mathrm{~N}-14.9 \mathrm{P}-0 \mathrm{~K}$ was injected to supply $\mathrm{N}$ at a rate of $0.04 \mathrm{~kg} \cdot \mathrm{ha}^{-1} \mathrm{~N}$ and $0.16 \mathrm{~kg} \cdot \mathrm{ha}^{-1} \mathrm{P}$. Nitrogen in the form $15.5 \mathrm{~N}-0 \mathrm{P}-0 \mathrm{~K}$ was injected biweekly between 10 Apr. and 1 May 2018 at a rate of $7.3 \mathrm{~kg} \cdot \mathrm{ha}^{-1}$ and a final application on 8 May 2018 at a rate of $1.8 \mathrm{~kg} \cdot \mathrm{ha}^{-1}$. In 2019 , nitrogen in the form of $15.5 \mathrm{~N}-0 \mathrm{P}-0 \mathrm{~K}$ was injected at a rate of $7.3 \mathrm{~kg} \cdot \mathrm{ha}^{-1}$ biweekly from 12 Mar. to 7 May.

Single and tank mix PRE herbicide treatments were assigned to experimental plots according to a randomized complete block design. Herbicides were applied on top of the planting bed at required rates according to their respective label rates using a pressurized $\mathrm{CO}_{2}$ backpack sprayer. Spray output was 187 $\mathrm{L} \cdot \mathrm{ha}^{-1}$ and Teejet TT 110025 nozzles (Teejet Technologies, Glendale Heights, IL) were used to apply treatments. The pendimethalin single treatment was not included in the second year due to tank herbicide contamination. Before herbicide application, T-Tape irrigation drip tape (Rain-Flo, East Earl, PA) with a wall thickness of 6-mils was installed at a depth of $8 \mathrm{~cm}$. Emitter spacing was 30 $\mathrm{cm}$, and emitter flow rate was 0.0032 $\mathrm{L} \cdot \mathrm{h}^{-1} \cdot \mathrm{m}^{-1}$, which supplied irrigation at a rate of $25 \mathrm{~mm} \cdot$ week $^{-1}$. Each row was covered with black, 4-mil very impermeable (VIF) polyethylene mulch (Berry Global, Evansville, IN) immediately after herbicide treatments were applied.

Double staggered rows were established with a mechanical planter with double hole puncher planting wheel, which created inverted-pyramidal-shaped holes with a volume of $4 \mathrm{~cm}^{3}$. Unconditioned plugs of 'Camarosa' strawberry plants having three to four trifoliate leaves were supplied by an in-state nursery (Triple J Nursery, Helena, AL). Plug plants were immediately set within each 9-m-long experimental plot on 17 Oct. 2017 and 20 Oct. 2018 for the 2018 and 2019 seasons, respectively. Staggered rows were spaced $30 \mathrm{~cm}$ apart and plants within a row were spaced $35.5 \mathrm{~cm}$ apart, resulting in 50 plants within each experimental plot or 44,800 plants/ha.

'Gulf' ryegrass (Lolium perenne) was seeded at a rate of $34 \mathrm{~kg} \cdot \mathrm{ha}^{-1}$ between rows to prevent soil erosion. After establishment, ryegrass was managed by mowing at 2-week intervals. Weed density in planting beds was minimal during both seasons; therefore, hand weeding of the nontreated control treatment plots was not needed.

Insect and fungal pest management was applied according to the recommendations of the Southeast Regional Strawberry Integrated Pest Management Guide for Plasticulture Production (Melanson et al., 2021). Fungicides and insecticides were applied from 28 Feb. to 1 June in 2018 and from 26 Mar. to 1 June in 2019.

One whole plant per replication was randomly selected for destructive harvest to determine plant mass from leaf surface area, shoot dry weight, and root dry weight. Whole plants were harvested at 6-week intervals during both seasons on 1 Dec. 2017, 10 Jan. 2018, 20 Feb. 2018, 12 Dec. 2018, 23 Jan. 2019, and 21 Mar. 2019. Leaf surface areas were measured using a LI-3100 leaf area meter (LI-COR Biosciences, Lincoln, NE). Leaf area ratio (LAR) was calculated using the following equation (Fernandez et al., 2001):

$$
L A R=\frac{\mathrm{LSA}}{\mathrm{LW}},
$$

where LSA is leaf surface area in $\mathrm{mm}^{2}$ and LW is leaf weight in grams.

Root and shoot dry weights were measured by separating the roots from foliage. Roots were washed to remove all soil and placed in brown paper bags. Foliage samples were placed in separate bags. Root and shoot samples were placed in a drying oven at $77^{\circ} \mathrm{C}$ for $10 \mathrm{~d}$ and then weighed. Root and shoot dry weights were combined to determine plant weight.

Relative growth rate (RGR) was calculated using the following equation (Fernandez et al., 2001):

$$
R G R=\frac{\ln P D W 2-\ln P D W 1}{\mathrm{~T} 2-\mathrm{T} 1},
$$

where $\operatorname{lnPDW} 2$ is the natural log of plant dry weight 2 and $\operatorname{lnPDW} 1$ is the natural $\log$ of plant dry weight 1 . T2 is time the second 
plant dry weight was taken and $\mathrm{T} 1$ is time the first dry weight was taken.

Strawberries were harvested 15 times from 26 Mar. to May 25 in 2018. In 2019, there were 13 harvests from 30 Mar. to 24 May. Removal of three plants within each plot to accommodate plant growth parameter data measurements resulted in yield being collected from 47 plants per plot. Harvest data included marketable yield, nonmarketable yield, and individual berry weight. Berries weighing less than $12 \mathrm{~g}$ were considered nonmarketable. To determine size of berries $<12 \mathrm{~g}$, a single berry sample weighing $12 \mathrm{~g}$ was used as a visual guide. Most nonmarketable fruit were a result of reduced berry size, but occasionally severely misshapen or diseased berries were included. Individual berry weight was determined by weighing 25 randomly selected marketable berries in each replication and dividing the weight by 25 .

Statistics. An analysis of variance was performed on all responses using PROC GLIMMIX in SAS version 9.4 (SAS Institute, Cary, NC). The studies were randomized complete block designs. Year and block were in the model as random variables. The treatment design was a one-way design of herbicide treatments for yield responses, and a two-way factorial of herbicide treatments and sample dates for fruit responses. Differences among herbicide treatment least squares means were tested using the simulate method. All significances were at $\alpha=0.05$.

\section{Results}

Shoot dry weight was unaffected by herbicide treatments at 6 or 12 weeks after planting (WAP) (Table 1). By 18 WAP, sulfentrazone, napropamide, and terbacil tank mixes with pendimethalin significantly reduced shoot dry weight $(6.8,5.71$, and $6.83 \mathrm{~g}$, respectively) when compared with pendimethalin (11.92 g) alone. In addition, napropamide + pendimethalin tank mix reduced plant dry weight compared with pendimethalin applied alone (Table 2). Tank mixes with $S$-metolachlor did not reduce shoot dry weight or plant dry weight compared with the nontreated control. Shoot and plant dry weights of all treatments were similar to the control.

Root dry weights were similar at 6 and 18 WAP, but terbacil $+S$-metolachlor was found to have higher root dry weight than pendimethalin at 12 WAP (Table 3). Nevertheless, tank mixes did not reduce root dry weights compared with the control.

Relative growth rate (Table 4) was unaffected by herbicide treatments during the period between 6 and 12 WAP $(P=0.7843)$ and 12 and 18 WAP $(P=0.1639)$. During the 6 to 18 WAP period, pendimethalin + napropamide tank mix was found to reduce RGR $\left(0.007 \mathrm{~g} \cdot \mathrm{d}^{-1}\right)$ compared with the single application of pendimethalin $\left(0.014 \mathrm{~g} \cdot \mathrm{d}^{-1}\right)$ as well as the control $\left(0.15 \mathrm{~g} \cdot \mathrm{d}^{-1}\right)$. Furthermore, leaf area ratio was unaffected by treatments (data not shown).
Table 1. Effects of preemergence herbicides on shoot dry weight of 'Camarosa' strawberry plants at Clanton, AL.

\begin{tabular}{lllc}
\hline Treatment $^{\mathrm{z}}$ & $6 \mathrm{WAP}$ & $12 \mathrm{WAP}$ & $18 \mathrm{WAP}^{\mathrm{y}}$ \\
\hline Pendimethalin $^{\mathrm{x}}$ & 3.40 & 4.91 & $11.92 \mathrm{a}$ \\
Terbacil & 2.96 & 5.16 & $8.86 \mathrm{abc}$ \\
Sulfentrazone + pendimethalin & 2.91 & 3.79 & $6.8 \mathrm{bc}$ \\
Sulfentrazone & 2.84 & 4.66 & $8.99 \mathrm{abc}$ \\
Napropamide $+S$-metolachlor & 2.57 & 3.36 & $6.13 \mathrm{bc}$ \\
Napropamide + pendimethalin & 2.56 & 4.62 & $5.71 \mathrm{c}$ \\
Terbacil $+S$-metolachlor & 2.45 & 3.88 & $6.76 \mathrm{bc}$ \\
Sulfentrazone $+S$-metolachlor & 2.43 & 4.59 & $9.81 \mathrm{ab}$ \\
Control & 2.42 & 4.40 & $8.09 \mathrm{abc}$ \\
$S$-metolachlor & 2.40 & 3.83 & $6.44 \mathrm{bc}$ \\
Terbacil + pendimethalin & 2.37 & 3.83 & $6.83 \mathrm{abc}$ \\
Napropamide & 2.10 & 4.27 & $6.4 \mathrm{bc}$ \\
$P$ value & 0.2651 & 0.3086 & 0.0002 \\
\hline Valus
\end{tabular}

${ }^{\mathrm{z}}$ Values calculated from a single plant per replication at each sample collection period. Weeks after planting (WAP) occurred on the following dates 1 Dec. 2107, 10 Jan. 2018, 12 Dec. 2018, 23 Jan. 2019, and 21 Mar. 2019.

${ }^{\mathrm{y}}$ Means with different letters indicate significant differences. Least squares means comparisons among treatments using the simulated method at $P<0.05$.

${ }^{\mathrm{x}}$ Pendimethalin single-applied treatment was not included in 2019.

Table 2. Effects of preemergence herbicides on root dry weight of 'Camarosa' strawberry plants at Clanton, AL.

\begin{tabular}{llcc}
\hline Treatment $^{\mathrm{z}}$ & $6 \mathrm{WAP}$ & $12 \mathrm{WAP}^{\mathrm{y}}$ & $18 \mathrm{WAP}$ \\
\hline Pendimethalin & 1.55 & $1.53 \mathrm{~b}$ & 4.83 \\
Terbacil & 1.64 & $2.00 \mathrm{ab}$ & 3.66 \\
Sulfentrazone + pendimethalin & 1.31 & $2.03 \mathrm{ab}$ & 3.91 \\
Sulfentrazone & 1.41 & $2.58 \mathrm{ab}$ & 3.61 \\
Napropamide $+S$-metolachlor & 1.42 & $2.26 \mathrm{ab}$ & 4.08 \\
Napropamide + pendimethalin & 2.03 & $3.19 \mathrm{ab}$ & 2.67 \\
Terbacil $+S$-metolachlor & 1.42 & $3.65 \mathrm{a}$ & 4.46 \\
Sulfentrazone $+S$-metolachlor & 1.28 & $2.74 \mathrm{ab}$ & 4.66 \\
Nontreated control & 1.06 & $2.02 \mathrm{ab}$ & 4.31 \\
$S$-metolachlor & 1.71 & $3.17 \mathrm{ab}$ & 3.93 \\
Terbacil + pendimethalin & 1.48 & $1.92 \mathrm{ab}$ & 3.57 \\
Napropamide & 1.40 & $2.57 \mathrm{ab}$ & 4.27 \\
$P$ value & 0.1333 & 0.0123 & 0.6524 \\
\hline
\end{tabular}

${ }^{\mathrm{z}}$ Values calculated from a single plant per replication at each sample collection period. Weeks after planting (WAP) occurred on the following dates 1 Dec. 2107, 10 Jan. 2018, 12 Dec. 2018, 23 Jan. 2019, and 21 Mar. 2019.

${ }^{\mathrm{y}}$ Means with different letters indicate significant differences. Least squares means comparisons among treatments using the simulated method at $P<0.05$.

${ }^{x}$ Pendimethalin single-applied treatment was not included in 2019.

Table 3. Effects of preemergence herbicides on plant dry weight of 'Camarosa' strawberry plants at Clanton, AL.

\begin{tabular}{llcc}
\hline Treatment $^{\mathrm{z}}$ & $6 \mathrm{WAP}$ & $12 \mathrm{WAP}$ & $18 \mathrm{WAP}^{\mathrm{y}}$ \\
\hline Pendimethalin $^{\mathrm{x}}$ & 4.95 & 6.44 & $16.74 \mathrm{a}$ \\
Terbacil & 4.60 & 7.16 & $12.52 \mathrm{ab}$ \\
Sulfentrazone + pendimethalin & 4.21 & 5.76 & $10.71 \mathrm{ab}$ \\
Sulfentrazone & 4.25 & 7.24 & $12.60 \mathrm{ab}$ \\
Napropamide $+S$-metolachlor & 3.98 & 5.62 & $10.21 \mathrm{ab}$ \\
Napropamide + pendimethalin & 4.59 & 7.80 & $8.37 \mathrm{~b}$ \\
Terbacil $+S$-metolachlor & 3.86 & 7.54 & $11.21 \mathrm{ab}$ \\
Sulfentrazone $+S$-metolachlor & 3.71 & 7.33 & $14.47 \mathrm{ab}$ \\
Nontreated control & 3.48 & 6.43 & $12.43 \mathrm{ab}$ \\
$S$-metolachlor & 4.10 & 7.00 & $10.36 \mathrm{ab}$ \\
Terbacil + pendimethalin & 3.85 & 5.82 & $10.40 \mathrm{ab}$ \\
Napropamide & 3.50 & 6.84 & $10.68 \mathrm{ab}$ \\
$P$ value & 0.2750 & 0.2711 & 0.0235 \\
\hline
\end{tabular}

${ }^{\mathrm{Z}}$ Values calculated from a single plant per replication at each sample collection period. Weeks after planting (WAP) occurred on the following dates 1 Dec. 2107, 10 Jan. 2018, 12 Dec. 2018, 23 Jan. 2019, and 21 Mar. 2019.

${ }^{\mathrm{y}}$ Means with different letters indicate significant differences. Least squares means comparisons among treatments using the simulated method at $P<0.05$.

${ }^{x}$ Pendimethalin single-applied treatment was not included in 2019. 
Table 4. Effects of preemergence herbicides on relative growth rate of 'Camarosa' strawberry plants at Clanton, AL.

\begin{tabular}{|c|c|c|c|}
\hline Treatment $^{\mathrm{z}}$ & 6-12 WAP & $12-18$ WAP & $6-18 \mathrm{WAP}^{\mathrm{y}}$ \\
\hline Napropamide & 0.013 & 0.003 & $0.13 \mathrm{ab}$ \\
\hline Nontreated control & 0.12 & 0.007 & $0.15 \mathrm{a}$ \\
\hline Sulfentrazone $+S$-metolachlor & 0.012 & 0.007 & $0.015 \mathrm{a}$ \\
\hline Sulfentrazone & 0.011 & 0.005 & $0.012 \mathrm{ab}$ \\
\hline Napropamide + pendimethalin & 0.010 & 0.001 & $0.007 \mathrm{~b}$ \\
\hline Terbacil $+S$-metolachlor & 0.010 & 0.002 & $0.012 \mathrm{ab}$ \\
\hline$S$-metolachlor & 0.009 & 0.004 & $0.012 \mathrm{ab}$ \\
\hline Terbacil + pendimethalin & 0.009 & 0.002 & $0.011 \mathrm{ab}$ \\
\hline Terbacil & 0.009 & 0.004 & $0.012 \mathrm{ab}$ \\
\hline Sulfentrazone + pendimethalin & 0.008 & 0.005 & $0.011 \mathrm{ab}$ \\
\hline Pendimethalin ${ }^{\mathrm{z}} \mathrm{P}$ & 0.005 & 0.013 & $0.014 \mathrm{ab}$ \\
\hline Napropamide $+S$-metolachlor & 0.004 & 0.007 & $0.01 \mathrm{ab}$ \\
\hline$P$ value & 0.7843 & 0.1639 & 0.0392 \\
\hline
\end{tabular}

${ }^{\mathrm{z}}$ Values calculated from a single plant per replication at each sample collection period. Weeks after planting (WAP) occurred on the following dates 1 Dec. 2107, 10 Jan. 2018, 12 Dec. 2018, 23 Jan. 2019, and 21 Mar. 2019.

${ }^{\mathrm{y}}$ Means with different letters indicate significant differences. Least squares means comparisons among treatments using the simulated method at $P<0.05$.

${ }^{\mathrm{x}}$ Pendimethalin single-applied treatment was not included in 2019.
Differences were found in marketable yield $(P \leq 0.0001)$, nonmarketable yield $(P \leq 0.0001)$ and individual fruit weight $(P \leq 0.0001)$ (Table 5). Napropamide + pendimethalin $(5.0 \mathrm{~g} /$ plant/harvest) tank mix produced significantly lower nonmarketable fruit compared with sulfentrazone + pendimethalin (7.6 g/plant/harvest) tank mix and napropamide alone ( $7.6 \mathrm{~g} / \mathrm{plant} /$ harvest). Sulfentrazone single treatment produced smaller fruit (22.1) than the terbacil treatment $(23.8 \mathrm{~g})$. In each yield category, all herbicide treatments were similar to the control.

\section{Discussion}

The current study revealed potential risks to strawberry plant development and, to a lesser degree, crop yield when applying tank mixes of pendimethalin or $S$-metolachlor with napropamide, sulfentrazone, or terbacil under polyethylene mulch. Pendimethalin tank mixes significantly reduced shoot dry weight and one treatment, napropamide + pendimethalin, reduced whole plant dry weight compared with pendimethalin treatment applied alone. The effects of pendimethalin tank mixes on plant growth found in this study are consistent with Smith (2006) where a PRE tank mix application of pendimethalin and atrazine was found to reduce seedling growth of okra (Abelmoschus esculentus) and tossa jute (Corchorus olitorius L.) compared with pendimethalin alone $\left(0.33 \mathrm{~kg} \cdot \mathrm{ha}^{-1}\right.$ a.i.). Moreover, Jursík et al. (2019) found that pendimethalin + metazachlor reduced stem size of kohlrabi (Brassica oleracea). On the basis of these and findings, it is not surprising that at least one pendimethalin tank mix reduced RGR compared with pendimethalin alone in the current study. Pendimethalin tank mixes did not appear to affect root dry weight adversely, although root dry weight was higher in the terbacil $+S$-metolachlor tank mix.

Yield and fruit size. Strawberry leaf number and plant size correlate with fruit number and size, respectively. The most vigorous plants typically produce higher yields than plants with low vigor; therefore, herbicide use can influence yield by reducing plant size through injury (Cocco et al., 2011). Although pendimethalin tank mixes appeared to affect plant size (and in one case RGR) adversely, there was no reciprocal reduction in marketable yield compared with pendimethalin alone or the control.

Terbacil or $S$-metolachlor when applied alone have been shown to be problematic
Table 5. Effects of selected tank mixed and single applied preemergence herbicides on marketable yield, nonmarketable yield, and individual fruit weight of 'Camarosa' strawberry plants grown at Clanton, $\mathrm{AL}^{\mathrm{z}}$

\begin{tabular}{lccc}
\hline Treatment & $\begin{array}{c}\text { Marketable wt } \\
(\mathrm{g} / \text { plant/harvest })\end{array}$ & $\begin{array}{c}\text { Nonmarketable wt } \\
(\mathrm{g} / \text { plant/harvest })\end{array}$ & $\begin{array}{c}\text { Individual } \\
\text { fruit wt }(\mathrm{g})\end{array}$ \\
\hline Terbacil & $27.0 \mathrm{a}$ & $7.1 \mathrm{ab}$ & $23.8 \mathrm{a}$ \\
Terbacil + pendimethalin & $26.6 \mathrm{ab}$ & $6.7 \mathrm{ab}$ & $23.2 \mathrm{ab}$ \\
Sulfentrazone & $26.0 \mathrm{ab}$ & $7.0 \mathrm{ab}$ & $22.1 \mathrm{~b}$ \\
Napropamide + pendimethalin & $25.5 \mathrm{ab}$ & $5.0 \mathrm{~b}$ & $23.6 \mathrm{ab}$ \\
Pendimethalin & $25.4 \mathrm{abc}$ & $6.2 \mathrm{ab}$ & $22.7 \mathrm{ab}$ \\
Nontreated control & $25.0 \mathrm{abc}$ & $5.1 \mathrm{ab}$ & $22.5 \mathrm{ab}$ \\
$S$-metolachlor & $24.6 \mathrm{abc}$ & $6.0 \mathrm{ab}$ & $23.3 \mathrm{ab}$ \\
Sulfentrazone + pendimethalin & $24.5 \mathrm{abc}$ & $7.6 \mathrm{a}$ & $22.5 \mathrm{ab}$ \\
Sulfentrazone $+S$-metolachlor & $24.2 \mathrm{abc}$ & $6.5 \mathrm{ab}$ & $22.3 \mathrm{ab}$ \\
Napropamide & $23.3 \mathrm{abc}$ & $7.6 \mathrm{a}$ & $22.2 \mathrm{ab}$ \\
Napropamide $+S$-metolachlor & $23.2 \mathrm{bc}$ & $5.4 \mathrm{ab}$ & $23.0 \mathrm{ab}$ \\
Terbacil $+S$-metolachlor & $21.4 \mathrm{c}$ & $5.7 \mathrm{ab}$ & $22.7 \mathrm{ab}$ \\
$P$ value & $<0.0001$ & $<0.0001$ & $<0.0001$ \\
\hline
\end{tabular}

${ }^{\mathrm{z}}$ Least squares means comparisons among treatments using the simulated method at $P<0.05$. when used in strawberries (Boyd and Reed 2016; Polter et al., 2005). In the current study, tank mixing $S$-metolachlor and terbacil tended to reduce marketable yield compared with terbacil alone.

Most tank mix and single applied treatments in this study did not affect plant growth or yield parameters compared with the control. Differences, when found, were primarily between pendimethalin and $S$-metolachlor applied alone and one of the corresponding tank mixes. Moreover, these herbicides were determined to be safe to use to control weeds in other crops based on findings in studies mentioned previously.

\section{Conclusion}

Spray programs that combine modes of action of different herbicides might increase the risk of phytotoxicity and reduced yield, although they provide protection from a larger number of weed species. Although results of the current study on occasion supported previous findings of potential crop injury, herbicides applied alone or as tank mixes appeared safe for use in annual hill plasticulture production of strawberries when compared with a nontreated control. Additional studies are needed to determine feasibility of acquiring special local needs status for one or more of these herbicide technologies for immediate use in Alabama in strawberries.

\section{Literature Cited}

Adcock, C.W., W.G. Foshee, III, G.R. Wehtje, and C.H. Gilliam. 2008. Herbicide combinations in tomato to prevent nutsedge (Cyperus esculentus) punctures in plastic mulch for multi-cropping systems. Weed Technol. 22:136-141, doi: 10.1614/WT-07-060.1.

Alabama Cooperative Extension. 2013. AL Pest Mgt. Hdbk. II. ANR-0500-B. <https://ssl.acesag. auburn.edu/pubs/docs/A/ANR-0500-B/ANR-0500B-archive.pdf $>$.

Awan, T.H., P.C. Sta Cruz, and B.S. Chauhan. 2015. Agronomic indices, growth, yield-contributing traits, and yield of dry-seeded rice under varying herbicides. Field Crops Res. 177: 15-25, doi: 10.1016/j.fcr.2015.03.001.

Boyd, N.S. and T. Reed. 2016. Strawberry tolerance to bed-top and drip-applied preemergence herbicides. Weed Technol. 30:492-498, doi: 10.1614/WT-D-15-00149.1.

Brault, D., K.A. Stewart, and S. Jenni. 2002. Optical properties of paper and polyethylene mulches used for weed control in lettuce. HortScience 37:87-91, doi: 10.21273/HORTSCI. 37.1.87.

Butler, L.M., G.E. Fernandez, and F.J. Louws. 2002. Strawberry plant growth parameters and yield among transplants of different types and from different geographic sources, grown in a plasticulture system. HortTechnology 12: 100-103, doi: 10.21273/HORTTECH.12.1.100.

Cocco, C., J.L. Abdruiki, F.L. Cardisi, L. Erpen, and O.J. Schmitt. 2011. Crown size and transplant type on the strawberry yield. Sci. Agr. 68:489-493, doi: 10.1590/S0103-9016201100 0400015.

Daugovish, O., S.A. Fennimore, and R.F. Smith. 2007. Herbicide evaluation for fresh market celery. Weed Technol. 21:719-723, doi: 10.16 14/WT-06-202.1. 
Fernandez, G.E., L.M. Butler, and F.J. Louws. 2001. Strawberry growth and development in an annual plasticulture system. HortScience 36: 1219-1223, doi: 10.21273/HORTSCI.36.7.1219.

Figueroa, R., D. Doohan, and J. Cardina. 2005. Efficacy and selectivity of promising herbicides for common groundsel control in newly established strawberry. HortTechnology 15:261-266, doi: 10.21273/HORTTECH.15.2.0261.

Himelrick, D.G., A.A. Powell, and W.A. Dozier, Jr. 2002. Commercial Strawberry Production. AL Coop. Ext. Serv. Bul. ANR-0633.

$\mathrm{Hu}$, C., M. Mohseni-Moghadam, and D. Doohan. 2017. Tolerance of strawberry cultivars to terbacil. Intl. J. Fruit Sci. 17:20-28, doi: 10.1080/ 15538362.2016.1212297.

Jursík, M., J. Šuk, M. Kolářová, and J. Soukup. 2019. Effect of irrigation and soil adjuvant on the efficacy and selectivity of pendimethalin and metazachlor in kohlrabi. Scientia Hort. 246: 871-878, doi: 10.1016/j.scienta.2018.11.062.

Kaushik, S., J.C. Streibig, and N. Cedergreen. 2006. Activities of mixtures of soil-applied herbicides with different molecular targets. Pest Mgt. Sci. 62:1092-1097, doi: 10.1002/ps.1285.

Ngouajio, M. and J. Ernest. 2004. Light transmission through colored polyethylene mulches affects weed populations. HortScience 39:1302-1304, doi: 10.21273/HORTSCI.39.6.1302.

Melanson, R.A., C.C. Johnson, M.H. Ferguson, J. Desaeger, H.J. Burrack, D. Pfeiffer, A. Sial, F. Hale, and K. Jennings. 2021. Southeast regional strawberry integrated pest management guide for plasticulture production. Univ. GA. Bul. 44 .

Mišović, M.M., Z.A. Broćić, N.M. Momirović, and B.C. Ŝnžar. 1997. Herbicide combination efficacy and potato yield in agro-ecological conditions of Dragačevo. Acta Hort. 462:363-368, doi: 10.17660/ActaHortic.1997.462.54.

Polter, S.B., D. Doohan, and J.C. Scheerens. 2005. The effect of irrigation on terbacil tolerance in field-grown strawberry. HortTechnology 15:560 564, doi: 10.21273/HORTTECH.15.3.0560.

Pritts, M.P. and M.J. Kelly. 2001. Early season weed competition reduces yield of newly planted matted row strawberries. HortScience 36:729-731, doi: 10.21273/HORTSCI.36.4.729.

Recker, R.A., J.G. Lauer, D.E. Stoltenberg, P.D. Mitchell, and V.M. Davis. 2015. Does timing influence the utility of reduced atrazine rates for proactive resistance management? Weed Technol. 29:464-471.

Samtani, J.B., C.R. Rom, H. Friedrich, S.A. Fennimore, C.E. Finn, A. Petran, R.W. Wallace, M.P. Pritts, G. Fernandez, C.A. Chase, C.
Kubota, and B. Bergefurd. 2019. The status and future of the strawberry industry in the United States. HortTechnology 19:11-24, doi: 10.21273/HORTTECH04135-18.

Sharpe, S.M., N.S. Boyd, P.J. Dittmar, G.E. MacDonald, and R.L. Darnell. 2018. Effect of temperature on clopyralid safety in strawberry. Weed Technol. 32:347-351.

Singh, M., M. Malik, A.H.M. Ramirez, and A.J. Jhala. 2011. Tank mix of saflufenacil with glyphosate and pendimethalin for broad-spectrum weed control in Florida citrus. HortTechnology 21:606615, doi: 10.21273/HORTTECH.21.5.606.

Smith, M.A.K. 2006. Comparing weed and crop seedling response to pre-emergence pendimethalin application in Corchorus olitorius and Abelmoschus esculentus. Crop Prot. 25:1221-1226, doi: 10.1016/j.cropro.2005.09.017.

Taylor, J.E., D. Charlton, and A. Yúnez-Naude. 2012. The end of farm labor abundance. Appl Econ. Perspect. Policy 34:587-598.

U.S. Department of Agriculture, National Agricultural Statistics Service. Quickstats. 13 Sept. 2020. nass.usda.gov.

Yu, J. and N.S. Boyd. 2017. Weed control with and strawberry tolerance to herbicides applied through drip irrigation. Weed Technol. 31:870-876, doi: 10.1017/wet.2017.63. 